\title{
Ethogram of three genetic groups of goats confined using monitoring video images
}

\author{
CLAUDETE MARIA DA SILVA*, DERMEVAL ARAÚJO FURTADO ${ }^{\text {, }}$ \\ ARIOSVALDO NUNES DE MEDEIROS ${ }^{c}$ EDILSON PAES SARAIVAc, \\ MÉRCIA CARDOSO DA COSTA GUIMARÃES ${ }^{\mathrm{d}}$, LAURA DA CONCEIÇÃO \\ ALMEIDA TOTA ${ }^{\mathrm{e}}$, KAROLINE BATISTA DE PAIVA LOPES ${ }^{\mathrm{e}}$
}

\begin{abstract}
The ethogram description of confined goats is an alternative that helps identify animals' behaviour, their main behavior and the importance of developing production systems that provide better welfare conditions. This paper aims to describe the ethogram of three genetic groups of confined goats: Azul, Moxotó and Graúna, through monitoring video images, using 9 animals kept in individual pens, monitored by video cameras mounted on the roof of each pen. As for the design and description of ethogram, 810 hours of video image were recorded and analysed, these being from being nine hours a day periods; three in the morning, afternoon and night. We identified 34 visual behaviours, which were grouped into eight categories according to their functional character: food $=4)$, social interaction $(\mathrm{n}=6)$, displacement $(\mathrm{n}=2)$, resting $(\mathrm{n}=3)$, grooming $(\mathrm{n}=4)$, neutral position $(\mathrm{n}=3)$, bipedal ( $\mathrm{n}=5$ ) and other activities $(\mathrm{n}=7)$. In conclusion, behaviors described in the ethogram were similar for all three genetic groups. Goats conduct their daily routine with sequences of behaviour that involve eating (food intake or selection) and resting or ruminating, with social interactions and other activities having happened more frequently in the afternoon and at that time in the afternoon before being provided with food.
\end{abstract}

Keywords: Food intake; grooming; rumination; social interaction; water intake.

\section{Introduction}

Small domestic ruminant breeding is an activity of great economic and social importance, especially in regions of countries with arid and semiarid climates (Silva et al., 2010). Goats are among the top animals to be domesticated, used primarily for food, meat and milk and for their derivatives (Granados et al., 2006). In north eastern Brazil these animals are quite rustic, adapted to conditions of arid and semiarid regions and, therefore, have adapted to environments where arid climatic conditions and topographical limitations are dominant, such as mountainous areas (Silva et al., 2006; Araújo et al., 2010).

Among the goats reared in the semiarid north eastern Brazil, Azul, Graúna and Moxotó are the genetic groups highlighted for being highly adapted to the tropical climate, whereas the majority are reared under extensive or semi-intensive systems (Rocha et al., 2009) showing, however, little information about their behaviour once confined. The confinement of these animals has been recommended for presenting benefits and advantages such as increased weight gain, lower mortality, reduced pasture stocking during fodder scarcity, sale date arrangement, and higher gain of final profits and acceleration of capital turnover (Almeida et al., 2004). Confinement is particularly recommended for semi-arid areas, especially during the dry season where a great lack of forage pastures can be observed (Lisboa et al., 2010).

Monitoring video images has been used in research for studying animal's behaviour, welfare and ethogram's development due to its efficiency and accuracy, since the animal's behaviour is not influenced by human presence, in addition to this it allows researchers to establish concrete observations and certainty of animals behaviour (Sevegnani et al. 2005; Silva et al. 2006; Barbosa Filho et al., 2007).

\footnotetext{
* Correspondence: Claudete Maria da Silva, Rodovia BR 079 - km 12 Areia PB 58.397-000. E-mail address: claudete_m_ silva@hotmail.com

a Doutoranda em Zootecnia, Universidade Federal da Paraíba, Areia, PB, Brasil.

b Departamento de Engenharia Agrícola, Universidade Federal de Campina Grande, Campina Grande, PB, Brasil.

Departamento de Zootecnia, Universidade Federal da Paraíba, Areia, PB, Brasil.

d Departamento de Zootecnia, Instituto Federal de Pernambuco, Barreiros, PE, Brasil

e Mestre em Engenharia Agrícola, Universidade Federal de Campina Grande, Campina Grande, PB, Brasil.
} 
A way of representing any kind of animal's behaviour is through the development of an ethogram, which serves as the initial focus of behavioural study due to its accurate catalogue of all animal behavioural procedures (Pakhretia \& Pirta, 2010). On the other hand, it also provides references from where it's possible to analyse the behaviour of confined species, allowing researchers to observe the level of stereotypical behaviours, which are abnormal or uncommon behaviours when in their natural environment. These studies include, for example, the act of biting or excessively licking an object, constant apathy, continuous aggression toward other nearby animals, etc. (Banks, 1992; Pandorfi et al., 2004; Medeiros, 2009).

Ethogram studies of goats raised in confinement are scarce, therefore it's important to know about these animals main behaviours when in different farming systems, so as to try and assign them to new forms of intensive animal husbandry system. Given the above, the aim of this paper is to elaborate and describe the confined goats' ethogram, emphasizing the main behaviour categories through monitoring images.

\section{Methods and Methods}

\section{Animals and Environment}

The experiment was conducted at the Small Ruminants Research Unit, which belongs to Agrarian Science Center of Federal University of Paraíba, Brazil, in São João do Cariri city, with an annual rainfall of $450 \mathrm{~mm} / y e a r$, latitude of $7^{\circ} 25^{\prime}$ $\mathrm{S}$ and longitude of $36^{\circ} 30^{\prime} \mathrm{W}$, elevation from 450 to $500 \mathrm{~m}$, average annual temperature of $26^{\circ} \mathrm{C}$ and relative humidity of $65 \%$. The climate is classified as BSh (hot semi-arid), according to Köpepn's classification. Described in Table 1 are the average environmental variables for the experiment site.

Nine non-castrated goats were used, three from each of the genotypes Azul, Graúna and

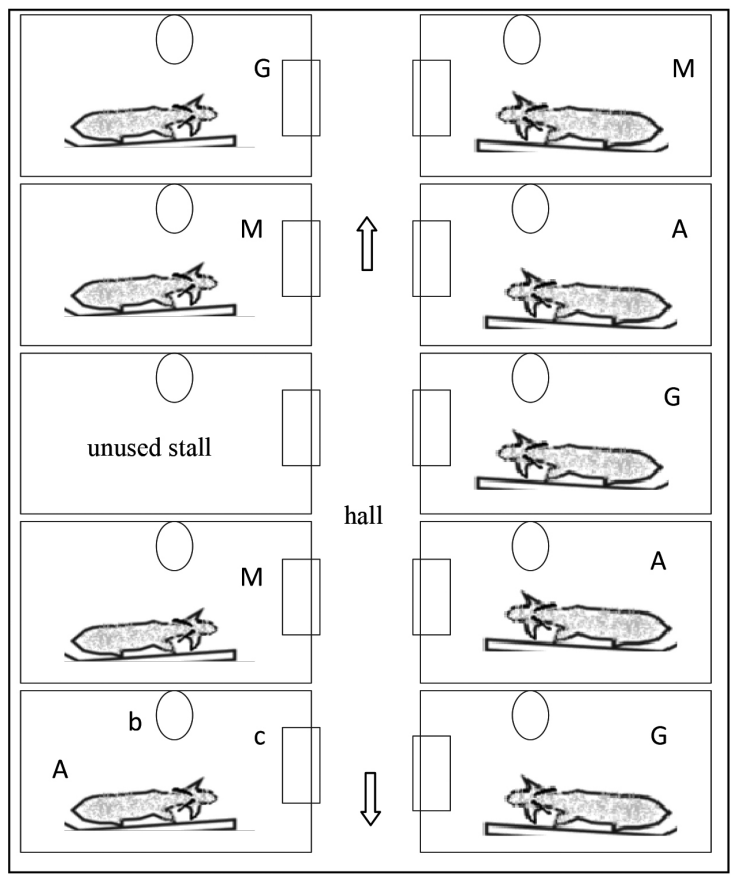

Figure 1. Animals disposed in individual stalls in the shed where they were kept confined during the experiment: drinker (b), trough (c), Azul (A) Graúna (G) and Moxotó (M).

Moxotó. Their initial average weight was $14.08 \mathrm{~kg}$, $15.22 \mathrm{~kg}$ and $15.74 \mathrm{~kg}$, respectively and their average age was 5 months old. They were confined for a period of 121 days, in which 21 days was for adapting to an open shed of $2.5 \mathrm{~m}$ high ceilings, wooden cover with ceramic tile shared into individual stalls (Fig. 1) sized $3.75 \mathrm{~m} \times 3.75 \mathrm{~m}$, dirt floor, containing 10 individual stalls with east-west orientation and access to shade and sun. The goats received individual water troughs and were fed with Buffel grass hay and concentrates twice a day at 7:30 am and then at 3:30 pm.

\section{Behavioural observations}

Day-Night TecVoz video cameras installed on the roof of each stall monitored the animals. All

Table 1 - Average values of the environment traits being air temperature (AT), relative humidity (RH), air velocity (AV), black globe humidity index (BGHI), temperature and humidity index (THI) and radiant thermal load (RTL)

\begin{tabular}{|c|c|c|c|c|c|c|}
\hline Periods & $\operatorname{AT}\left({ }^{\circ} \mathbf{G}\right)$ & RU (\%) & $\mathbf{A V}\left(\mathbf{m ~ s}^{-1}\right)$ & BGHI & THI & $\operatorname{RTL}\left(\mathbf{W} \mathbf{m}^{-2}\right)$ \\
\hline Morning & 26,93 & 55,7 & 1,63 & 77 & 74,23 & 526,66 \\
\hline Afternoon & 30,85 & 43,8 & 0,8 & 79,35 & 78,1 & 506,7 \\
\hline Night & 22,33 & 73,73 & 0,96 & 70,36 & 70,46 & 445,3 \\
\hline
\end{tabular}


cameras had cables connected to a computer where the images were processed and stored. The images were captured by a video capture board and transferred onto a computer and then recorded on DVD for visual analysis. The cameras were kept on 24 hours a day during 10 consecutive and interspersed days.

Ad libitum images (Martin \& Bateson, 1993) samples were collected in order to define and describe behavioural categories, establishing, later on, the animals' ethogram. 810 hours of video viewing during a 10 day recording period was required so as to study and observe the animals' behaviour. It took place in the morning, afternoon and evening, corresponding to 9 animals per 9 hours a day ( 3 hours each morning, afternoon and night). The analysed hours were, 8.00, 9.00 and $10.00 \mathrm{am}, 1.00,2.00$ and $3.00 \mathrm{pm}$ and $6.00,7.00$ and $8.00 \mathrm{pm}$, were recorded using the Windows Media Player with the aid of Etholog 2.2 software (Ottoni, 2000) for recording the frequency of different genetic group behaviour.

For the elaboration of the ethogram, different types of behaviour exhibited were described in relation to video image identification, frequency of each conduct and similar behaviour observed and studied in other species. Some ethological terms cited in the elaboration of ethogram followed existing models (Alados, 1984; Mooring et al., 1998; Prestes, 2000; Albuquerque \& Codenotti, 2006). Quantitative data were submitted to descriptive analysis, calculating the average frequency of the animals' behaviour.

\section{Results}

Throughout continuous image observation, 34 behaviours were identified and described in all genetic groups, which according to their functional characters were grouped into eight categories: feeding, social interaction, movement, resting, bipedal posture, grooming, neutral posture and other activities. Table 2 shows the average frequency of some of the behaviour.

\section{Feeding (four behaviors)}

(1) Food intake or selecting food: when the animal's head is positioned in the trough and remains uninterrupted selecting or consuming the food provided. During such actions the animals took small breaks to consume water and then return to the trough to continue their food intake. This behaviour was more frequent in the morning.
(2) Interaction trough: the goat approaches the trough, puts its head inside and removes it quickly without ingesting any food, supporting or putting a forelimb or staying with all four members inside the trough. This behaviour occurred more frequently in the morning.

(3) Water intake: the goat approaches and leans its head in the water fountain and drinks.

(4) Drinker interaction: the goat approaches or walks by the water trough without ingesting water. During this procedure it was observed a few times that the animal kept pushing the drinker with its horns and licking or biting it or even tripping it during fights with other goats that were near the water trough.

\section{Social Interaction}

When an animal influences other animals' behaviour whether from the same species or not. For this category the interactions were grouped in NonAgonistic Social and Agonistic Social interactions. The frequency of social interaction between animals was higher during the afternoon for all social behaviours (Table 2).

Social Non-Agonistic (three conducts)

(1) Play: the animals approach facing each other, both supported on the border of the stall in the bipedal position simulating fights, clashing their horns without aggressiveness. Scrubs or rubs of their noses on their peers neck with an up and down movement. Goats usually direct more attention to the neck, which remains upright. Sometimes the animals play while lying down, where they lightly clash the horns.

(2) Smelling other goats' genitalia: this behaviour was observed when the animals were standing around or lying down. With their head and neck stretched, the goat approaches its nose toward other animals' genitalia and sniffs or investigates it. When this behaviour occurs, the immediate response of the goat is to step away from the animal that is performing this behaviour. Sometimes during this procedure, the animal responds by clashing their horns so as to start a fight or simply walking away.

(3) Lye next to a goat or lye leaning - when lying very close the animals touch some body parts, whether 
Table 2 Average frequency of some behaviour seen in three genetic goat groups during the observed hours.

\begin{tabular}{|c|c|c|c|}
\hline \multirow{3}{*}{ Periods } & \multicolumn{3}{|c|}{ Genetic Groups } \\
\hline & Azul & Graúna & Moxotó \\
\hline & \multicolumn{3}{|c|}{ Food intake or selecting } \\
\hline Morning & 18.3 & 24.7 & 20.2 \\
\hline Afternoon & 5.9 & 11.2 & 8.7 \\
\hline \multirow[t]{2}{*}{ Night } & 7.6 & 11.8 & 3.4 \\
\hline & \multicolumn{3}{|c|}{ Interaction trough } \\
\hline Morning & 21.3 & 29.1 & 25.7 \\
\hline Afternoon & 11.2 & 23.7 & 16.3 \\
\hline \multirow[t]{2}{*}{ Night } & 13.7 & 24.2 & 8.4 \\
\hline & \multicolumn{3}{|c|}{ Water intake } \\
\hline Morning & 3.50 & 3.97 & 2.60 \\
\hline Afternoon & 1.50 & 1.57 & 0.60 \\
\hline \multirow[t]{2}{*}{ Night } & 0.20 & 0.17 & 0.03 \\
\hline & \multicolumn{3}{|c|}{ Drinker interaction } \\
\hline Morning & 3.07 & 4.10 & 2.13 \\
\hline Afternoon & 2.63 & 4.30 & 1.40 \\
\hline \multirow[t]{2}{*}{ Night } & 0.30 & 0.90 & 0.17 \\
\hline & \multicolumn{3}{|c|}{ Social interaction } \\
\hline Morning & 3.63 & 1.73 & 3.47 \\
\hline Afternoon & 5.50 & 3.53 & 6.00 \\
\hline \multirow[t]{2}{*}{ Night } & 3.63 & 1.17 & 3.60 \\
\hline & \multicolumn{3}{|c|}{ Lying in shade } \\
\hline Morning & 7.33 & 5.33 & 4.23 \\
\hline Afternoon & 7.13 & 6.03 & 5.67 \\
\hline \multirow[t]{2}{*}{ Night } & - & - & - \\
\hline & \multicolumn{3}{|c|}{ Lying exposed to sun } \\
\hline Morning & 2.40 & 1.10 & 0.50 \\
\hline Afternoon & 1.33 & 0.93 & 0.67 \\
\hline \multirow[t]{2}{*}{ Night } & - & - & - \\
\hline & \multicolumn{3}{|c|}{ Grooming } \\
\hline Morning & 21.50 & 24.27 & 27.33 \\
\hline Afternoon & 20.10 & 31.17 & 31.30 \\
\hline \multirow[t]{2}{*}{ Night } & 35.63 & 39.23 & 39.93 \\
\hline & \multicolumn{3}{|c|}{ Bipedal } \\
\hline Morning & 2.13 & 1.80 & 3.67 \\
\hline Afternoon & 3.43 & 2.93 & 4.87 \\
\hline \multirow[t]{2}{*}{ Night } & 4.20 & 1.53 & 3.07 \\
\hline & \multicolumn{3}{|c|}{ Other activities } \\
\hline Morning & 51.27 & 55.47 & 61.90 \\
\hline Afternoon & 54.17 & 69.37 & 70.57 \\
\hline Night & 61.93 & 55.73 & 62.77 \\
\hline
\end{tabular}

Morning (8:00-11:00h); Afternoon (13:00-16:00h); Night (18:00-21:00h). 
the rib or hip region, remaining laid down for rest or rumination. Sometimes during this conduct the goats shook their horns and head, without assuming any aggressive act, which looked like they were playing.

Social Agonistic (two behaviours)

The agonistic behaviour among animals is the one that involves fighting, aggression, defence, submission or withdrawal of intra-specific or harmony between animals. Two different ways to impose this behaviour were recorded: wrestling and gently clashing horns on the opponent's body.

(1) Fighting: the wrestling between goats is done in two ways: in normal and bipedal position.

When in normal position, the goats maintain their four legs on the floor, their heads down, ears back and with a quick movement, they clash their horns. The fights between goats in the normal position occur in a sequence of behaviours: approach, threat with its head towards the opponent and retreating from each other, at the exact moment they lower their heads and clash horns. They repeat this behaviour by moving their body backward and then forward facing the opponent and, again, clashing their horns. Animals stop leaving a distance between each other and strike their heads when their bodies are at right angles.

Once in a bipedal position, one of the animals raises their forelimbs, supporting them on the border of the stall and remaining their hind limbs on the floor, and strokes with the horns against an opponent that is also in a bipedal position. With both animals supported in the bay, they clash each other's horns. This practice is very common among animals, even sometimes when a goat that is interacting advances in fight attack in a bipedal position toward its peer, this one goes away to later return to attack.

(2) Gently hits the opponent's body using the horns: this happens during fights, helping to encourage the opponent to either start or continue the fight. It consists of hitting the flank or ribs of the opponent with the edges of the horns while it is lying down or even standing but with no interest in fighting. As a consequence, the goat stands up and starts fighting.
Displacement (two conducts)

(1) Walking/hiking in the stall: the goat moves around from one space to another, taking relatively short and slow steps, characterized when their forelimbs and hind limbs are moving alternately. This behaviour occurs when the animal, feeling satisfied after having eaten, walks around the stall searching for a place to lie down where after a while, it stands up, walks toward the trough to continue ingesting food or not. It also goes to the water trough whether to drink water or not and then approaches other goats for social interaction.

(2) Running: the goat runs in the stall whenever someone who enters the area sees it or even when a person approaches the animal. This behaviour is probably an escape reaction, due to the goat's quick movement in the opposite direction of the people who entered the stall.

\section{Resting (three conducts):}

(1) Lying in the shade: the goat remains lying down in a shaded space of the stall in order to rest or ruminate. Generally, goats have different habits to this behaviour, whether lying down with the entire surface, neck and head on the floor and forelimbs and hind limbs stretched, or lying down with the ventral region facing the floor and legs positioned under the neck while the head is settled on one of the hind limbs, or even with the side lying on the floor and forelimb and hind limbs stretched but crossed, moving its head and using its horns for grooming actions (Table 2).

(2) Lying exposed to the sun: The goat remains lying down exposed to the sun for a short period either to rest or ruminate (Table 2 ).

(3) Lying at night: goat remains lying down at night with different lying positions. During the night, while lying down, the animals also establish social interaction and perform grooming behaviour.

\section{Bipedal Posture}

The goat maintains its forelimbs supported above the slats that form the stall, standing upright but keeping the hind limbs from making contact with the floor. The animal takes this stance in different types of behaviours: It stays in a bipedal 
posture to socially interact in fights and games or watch another animal; it bites or licks the wooden column that supports the stall's facility; when someone approaches the trough to provide food or other management around the facility; and bipedal posture without any function or not fitting the ones mentioned before. Goats often assume this posture during food intake during grazing. The Animals' behaviours in bipedal posture were more frequent in the afternoon (Table 2).

Grooming

For this action the goat uses its teeth, horns or hind limbs to scratch, or it rubs any of its body parts in a wooden column in order to remove ectoparasites. Grooming is performed in two ways: oral, using the teeth directed to almost all parts of its body, except the head and neck, and non-oral or the act of scratching with a hind limb or horns, directed to head, neck, ribs and other parts of its body. Grooming behaviour was more frequent at night (Table 2).

\section{Neutral Posture}

(1) Standing in the shade: behaviour in which the animal stands still in a shaded area of the stall showing no displacement/movement or any other activity.

(2) Standing in the sun: behaviour in which the animal stands still in a sunny area of the stall showing no displacement/movement or any other activity.

(3) Standing at night: behaviour in which the animal stands still at night, showing no displacement/movement or any other activity.

\section{Other Activities}

When the goat performs a number of activities across the stall which do not fall into any of the behaviours described above. In this category seven behaviours were observed and described by their average frequency as shown in Table 2.

(1) Pushing the stall's gate and putting its head between the slats: a restless behaviour performed by goats possibly as a desire to leave or escape, or even distraction to see something or get a wider view of the location outside the stall, explained by their natural curiosity. For this procedure the goat uses its horns or a forelimb to push the stall. This behaviour leads to a sequence of movements, such as pushing the gate with the horns with constant back and forth intense movement, putting its head in the space between two slats while still being in a position of awareness so as to watch what is in front. When they do this the animal's effort to withdraw its head is sometimes noticeable.

(2) Exploratory behaviour: goats' characterized behaviour in which the animal explores its territory. The animal lowers its head toward the floor touching its snout as if looking for something.

(3) Scraping the stall's floor using the forelimbs: this is performed mostly when the animal is about to lie down. Using a forelimb, the goat scrapes the floor and then lies down.

(4) Touching the slats with the snout: during this behaviour the snout touches the stall's slats and it looks as if the goat is licking or even biting the wood.

(5) Stretching: when the animal stretches its legs because it is sleepy or lazy. This is performed after having remained lying down for a long period. When it stands up, the goat walks smoothly, stretches its entire body by positioning and spreading its hind limbs behind while its neck and head are stretched forward.

(6) Supporting a forelimb: while standing, the goat supports one of its forelimbs somewhere in the stall. For this behaviour the goat uses the space between the slats and supports one of its forelimbs on the food or water troughs.

(7) Aware: when standing the goat moves its head slightly to the side, staring at what is around. Usually this is performed due to someone passing by or walking around the facility or also when another animal is approaching. This is more likely happen when the animal is at the trough consuming food, where in response the goat stops ingesting food, stands still and aware, gazing fixed at the animal or person who is approaching. Ceasing this behaviour, the goat returns to ingesting food or walks across the stall returning later to ingest food. Table 3 shows the illustrated scheme summary of the goats' ethogram and figures 2, 3 and 4 are images of some observed behaviours. 
Ethogram of three genetic groups of goats confined using monitoring video images

Table 3. Summary of the goats' ethogram with behavioural categories related to their main behaviours according to each functional character (Graúna, Azul and Moxotó).

\begin{tabular}{|c|c|}
\hline $\begin{array}{c}\text { Behavioural } \\
\text { category }\end{array}$ & Behaviours \\
\hline \multirow{4}{*}{ Feeding } & Food intake or selecting \\
\hline & Water intake \\
\hline & Interaction trough \\
\hline & Drinker interaction \\
\hline \multirow{4}{*}{ Social interaction } & Social Non-Agonistic \\
\hline & Games \\
\hline & Smelling or investigating other goats' genitalia \\
\hline & Lying next to another goat \\
\hline \multirow{2}{*}{ Displacement } & Walking around the stall \\
\hline & Running in the stall \\
\hline \multirow{3}{*}{ Resting } & Lying in the shade \\
\hline & Lying exposed to the sun \\
\hline & Lying at night \\
\hline \multirow{4}{*}{ Bipedal posture } & While playing \\
\hline & While wrestling \\
\hline & Biting or licking the wooden column \\
\hline & Bipedal position on top of the trough \\
\hline \multirow{4}{*}{ Grooming } & Using its teeth \\
\hline & Using its horns \\
\hline & Using one its hind limbs \\
\hline & Rubbing its body on the stall's wooden column \\
\hline \multirow{3}{*}{ Neutral posture } & Standing in the shade \\
\hline & Standing in the sun \\
\hline & Standing at night \\
\hline
\end{tabular}

Pushing the stall's gate and putting its head between the slats

Touching the slats with its snout

Exploratory behaviour

Other activities

Scraping the stall's floor using its forelimbs *

Stretching

Supporting a forelimb

Awareness

* Behavioural conduct observed only in the genotype Graúna. 


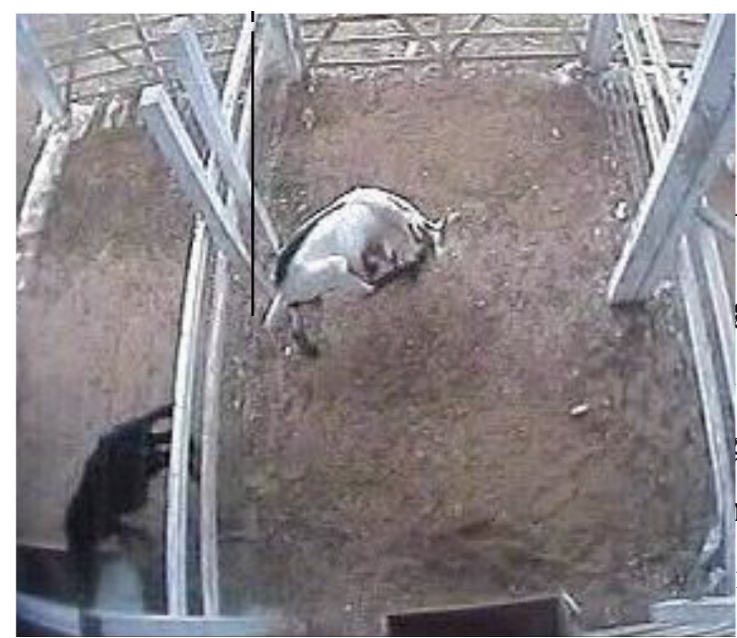

Figure 2. On the right - grooming (Moxotó), On the left consuming or selecting food (Graúna).

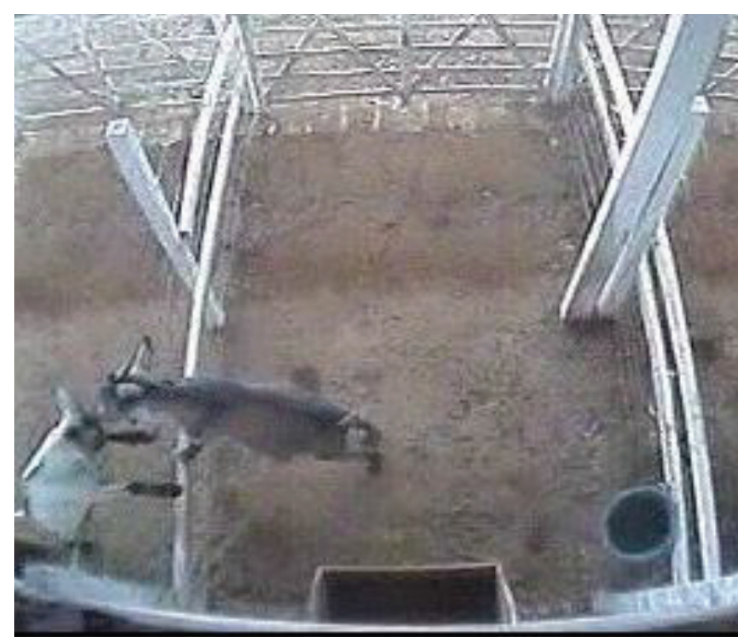

Figure 3. Animals in bipedal position with social behaviour characterized as playing (Azul and Moxotó).

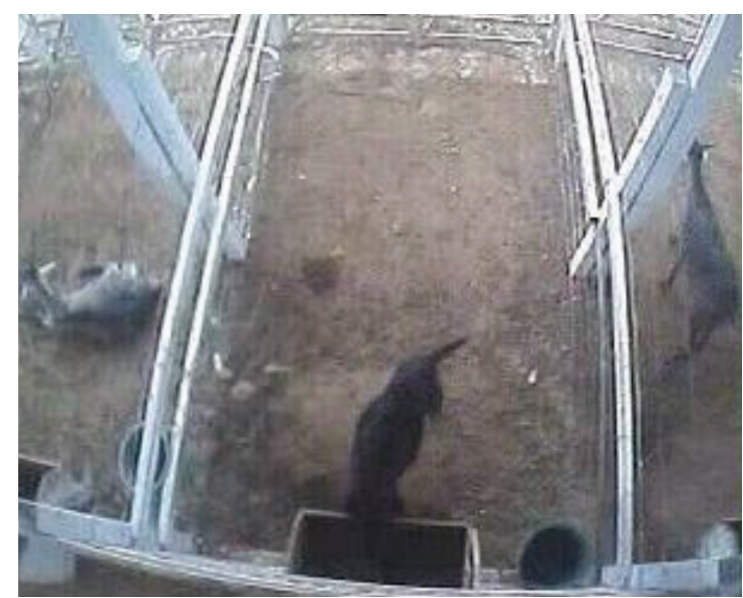

Figure 4. On the right, animal standing in the middle selecting or consuming food and on the left, animal lying down (Azul and Graúna).

\section{Discussion}

Goats are animals that are adapted to semiarid regions, where they are grown extensively, but can however have their performance compromised for not having access to food sources during dry periods, and is therefore important when confining these animals, especially during the summer season (Lisboa et al., 2010; Barreto et al., 2011). It was verified during this study that the animals maintained their dietary habits and behaviours similar to those ones raised in the field.

Most grazing activity occurs in the morning and late afternoon with quick consumption and a longer regurgitation process. They consume a large amount of food and then return to the trough for smaller meals (Ribeiro, 1997; Fischer et al., 2000). Once they return to the trough, other behaviours, such as remaining supported on the trough, can be developed as observed in this study.

As for water consumption, it was observed that the animals ingested the provided water at a lower frequency, which can be explained by their more efficient use of the water consumed (NRG, 2007; Araújo et al., 2010). Water intake is related to food intake because for nutrient digestion and absorption the water is required in the metabolic processes, which explains the higher frequency of water intake during the morning, in which there was also an increased frequency of food consumption (Table 2). When in field conditions, the animals seek water especially during the hottest hours of the day and in some cases, water is used as heat dissipation rather than shaded areas (Araújo et al., 2010).

Different social interaction behaviours between animals were observed and described in the ethogram, some similar to those cited by Alados (1984), when analysing mountain goat behaviour. The interactions between these animals clearly show signs of communication between them, and almost all social behaviour involve some sort of communication that can occur through a variety of forms, through sound, but also sight and touch (Goncalves Neto et al., 2009).

When animals are near others or live in an open habitat they can use signals, such as the use of their horns to establish communication (Weary \& Fraser, 2002). In the case of the goats studied, the most used form of communication was touch, especially with their horns, then with their forelimbs and also by touching their necks with their snouts. These behaviours were more frequently observed in the 
afternoon. When wrestling, the horns represent to the goats a source of power and strength, since the animals frequently use them when fighting for territory, food, females and control of the flock (Alados, 1984).

Vicente et al. (2002) reported that social behaviour among animals occur in two ways: Actor - Reactor: the animal initiates the social behaviour (actor) and the other animal receives that behavioural action and performs a behaviour in response (reactor); Actor - Receiver: the animal initiates the behaviour while the other serves as a receptor, responding to such conduct or not. These behavioural forms were observed in the genetic groups studied, in which a goat started behaviour, and then the other answered the directed conduct or not. Moxotó was the group that mostly interacted as an actor with the other animals especially with the Azul (reactor), while the Graúna interacted less.

Social behaviour serves many ecological purposes, interactional and relational; this provides several advantages such as better protection from predators, more efficient foraging, and ease of interactions related to sexual behaviours (Fraser \& Broom, 1990). However, once living in groups, things like competition for food or access to other resources can reduce harmony between animals (Estevez et al., 2007).

Orgeur et al. (1990) reported that in intensive goat production systems, levels of aggression are higher than those compared to semi-intensive and extensive systems. This was also verified by Barroso (2000) who reported that the frequency of aggressive interactions were higher among goats that were kept indoors than among goats on pastures, probably because of differences in space availability that was more limited indoors. Goats from the present study showed high anxiety for the hours that preceded food delivery, as well as that the proximity between the stalls where they were confined contributed to aggressive behaviour among them.

Grooming behaviour was more frequent at night, certainly due to a more intense presence of ectoparasites. This behaviour can be different according to species, among primates, for example, grooming is characterized by picking using hands to do so, this is called self-grooming, whereas in non-primate species grooming can be accomplished with the hind limbs, claws, hooves, horns and also with the use of the tongue or teeth. As for cattle, grooming is performed with the tongue by licking the pelage with the presence of ectoparasites. When grooming, the goats use the horns, teeth or hind limbs (Hart \& Pryor, 2003). According to McKenzie (1990), when they are grooming with their teeth, goats use their incisor teeth, which provides benefits in terms of control of ectoparasites but can, however, compromise goats oral hygiene besides wearing out the lower incisors, which may compromise food intake since the goats use their incisor teeth during their feeding habits (Zanine et al., 2006).

The bipedal posture is a characteristic behaviour that confers goats' advantages when under grazing conditions; they are also quite agile compared to sheep and cattle (Sanon et al., 2007). Ribeiro (1997) mentions that due to their eating habits and the way domestication was carried out, goats have a greater preference for high forage than cattle and sheep. Consequently once in natural conditions, they were free from catching the vast majority of endoparasites, therefore developing less resistance to them, since they were infested in a much less severe way than sheep and cattle, which had to develop resistance in order to survive. In the native goats studied, the animals were in the bipedal position in need of developing other behaviours such as, interacting socially, observing the arrival or approach of people, biting or licking the wooden column that supports the stall and bipedal posture without performing any other behaviour.

The frequency of other activities was higher in the afternoon for all genetic groups. The goats studied here showed similar behaviour to the mountain goats studied by Alados (1984) in Spain, where the goats scratched the ground with one of the forelimbs while grazing so as to dig up some tubers as well as when they were about to lye down, indicating common behaviour of these animals to those in Northeast Brazil that, even though confined, also performed these behaviours, although this behaviour was only observed in the Graúna group.

The animals were in an aware position either during the passage of people and other animals around the stall or even without any kind of disturbance. Goldstein et al. (2005) defined the awareness behaviour as the state where the goat stays with its head leaned toward some kind of stimulus. Quenette (1990) reported that animals standing aware are a sign of surveillance and that they stop what they are doing during their ongoing activity, raising their head and visually scanning the environment. This definition implies that the animals become aware without being bothered (Tracey \& Fleming, 2007). This awareness behaviour was also observed in the goats studied, which remained more aware when they received some kind of stimulus. While studying goats behaviour induced by real visual and acoustic 
stimuli, Staay et al. (2011) observed that for goats the aware state was higher whenever stimuli were provided, where then the goat lifted its head and turned it ears ahead towards the stimulus.

\section{Conclusion}

In Moxotó, Canindé and Graúna genetic groups, 34 distinct behaviours were observed and grouped into feeding, resting, neutral posture, bipedal posture, movement, self-cleaning and other activity categories, except for scraping the stall's floor behaviour, seen only in the Graúna genotype. Goats conduct their daily routine with sequences of behaviours involving eating (food intake or selection) and resting or ruminating, social interactions and other activities happen more frequently in the afternoon and at that time in the afternoon before the food is provided.

\section{Acknowledgments}

The authors thank the Universidade Federal da Paraíba and CNPq.

\section{References}

Alados, C. L. 1984. Etograma de la cabra montés (Capra pyrenaica) y comparación com otras especies. Acta Vertebrata, 11, 289-309.

Albuquerque, V. J. \& Codenotti, T. L. 2006. Etograma de um grupo de bugios-pretos, Alouatta caraya (Humboldt, 1812) (Primates, Atelidae) em um habitat fragmentado. Revista de Etologia, 8, 97-107.

Almeida JR, G. A., Costa, C., Monteiro, A. L. G., Garcia, C. A., Munari, D. P. \& Neres, M. A. 2004. Desempenho, características de carcaça e resultado econômico de cordeiros criados em creep feeding com silagens de grãos úmidos de milho. Revista Brasileira de Zootecnia, 33, $104-1059$.

Araújo, G. G. L., Voltolini, T. V., Chizzotti, M. L., Turco, S. H. N. \& Carvalho, F. F. R. 2010. Water and small ruminant production. Revista Brasileira de Zootecnia, 39, 326-336.

Banks, E. M. 1982. Behavioural research to answer questions about animal welfare. Fournal of Animal Science, 54, 434-455.
Barbosa Filho, J. A. D., Silva, I. J. O., Silva, M. A. N. \& Silva, G. J. M. 2007. Avaliação dos comportamentos de aves poedeiras utilizando seqüência de imagens. Engenharia Agrícola, 27, 93-99.

Barreto, L. M. G., Medeiros, A. N., Batista, A. M. V., Furtado, D. A., Araújo, G. G. L., Lisboa, A. C. C., Paulo, J. F. A. \& Souza, C. M. S. 2011. Comportamento ingestivo de caprinos das raças Moxotó e Canindé em confinamento recebendo dois níveis de energia na dieta. Revista Brasileira de Zootecnia, 40, 834-842.

Barroso, F. G., Alados, G. L. \& Boza, J. 2000. Social hierarchy in the domestic goat: effect behaviour in goats and sheep. Animal Behaviour, 67, 11-19.

Estevez, I., Andersen, I. L. \& Nævdal, E. 2007. Group size, density and social dynamics in farm animals. Applied Animal Behaviour Science, 103, 185-204.

Fischer, V., Dutilleul, P., Deswysen, A. G., Dèspres, L. \& Lobato, J. F. P. 2000. Aplicação de probabilidades de transição de estado dependentes do tempo na análise quantitativa do comportamento ingestivo de ovinos. Revista Brasileira de Zootecnia, 29, 1811-1820.

Fraser, A. F. \& Broom, D. M. 1990. Farm Animal Behaviour and Welfare. London: Bailliére Tindall.

Goldstein, M. I., Poe, A. J., Cooper, E., Youkey, D., Brown, B. A. \& Mcdonald, T. L. 2005. Mountain goat response to helicopter Overflights in Alaska. Wildlife Society Bulletin, 33, 688-699.

Gonçalves Neto, J., Teixeira, F. A., Nascimento, P. V. N. \& Marques, J. A. 2009. Comportamento Social de Ruminantes. Revista Eletrônica Nutritime, 6, 1039-1055.

Granados, L. B. C., Dias, Â. J. B. \& Sales, M. P. 2006. Aspectos gerais da reprodução de caprinos e ovinos elaboradores. Campos dos Goytacazes: Proex/Uenf.

Hart, B. \& Pryor, P. A. 2003.Developmental and hair-coat determinants of grooming behaviour in goats and sheep. Animal Behaviour, 67, 11-19.

Köppen, W. \& Geiger, R. Klimate der Erde. Gotha: Verlag Justus Perthes. 1928. Wall-map $150 \mathrm{~cm} x 200 \mathrm{~cm}$.

Lisboa, A. C. C, Furtado, D. A., Medeiros, A. N., Costa, R. G. Queiroga, R. C. R. E. \& Barreto, L. M. G. 2010. Quantitative characteristics of the carcasses of Moxotó 
and Canindé goats fed diets with two different energy levels. Brazilian Fournal of Animal Science, 39, 1566-1570.

Martin, B. \& Bateson, P. 1993. Measuring Behaviour: An introductory guide. UK: Cambridge University Press, 222.

Mckenzie, A. A. 1990. The ruminant dental grooming apparatus. Zoological Fournal of the Linnean Society, 99, 117-128.

Medeiros, L. F. D. 2009. Bem-estar e produção animal. Seropédica: RJ. Universidade Federal Rural do Rio De Janeiro.

Mooring, M. S., Gavazzi, A. J. \& Hart, B. L. 1998. Effects of castration on grooming of goats. Physiology $\mathcal{E}^{\circ}$ Behaviour, 64, 707-713.

NRG (National Research Council) 2007. Nutrient requirements of small ruminants: sheep, goats, cervids, and new world camelids. Washington, D.C.: National Academy Press.

Orgeur, P., Mimouni, P. \& Signoret, J. P. 1990.The Influence of Rearing conditions on the social relationships of young male goats. Applied Animal Behaviour Science, 27, 105-113.

Ottoni, E. B. EthoLog 2.2: 2000. A tool for the transcription and timing of behaviour observation sessions. In: Behaviour Research Methods, Intrumentos E Computers, 32, 446-449.

Pakhretia, S. \& Pirta, R. S. A. 2010. Behavioural Study of the Sheep and Goats of the Transhumant Gaddis. Fournal of Human Ecology, 29, 93-100.

Pandorfi, H., Silva, I. J. O., Moura, D. J. \& Sevegnani, K. B. 2004. Análise de imagem aplicada ao estudo do comportamento de leitões em abrigo escamoteador. Engenharia Agrícola, 24, 274-284.

Prestes, N. P. 2000. Descrição e análise quantitativa do etograma de Amazona petrei em cativeiro. Ararajuba, $8,25-42$.

Quenette, P. Y. 1990. Functions of vigilance behaviour in mammals: a review. Acta Oecologica, 11, 801-818.

Ribeiro, S. D. de A. 1997. Caprinocultura: Criação Racional de Caprinos. São Paulo: Edition - Nobel.
Rocha, R. R. C., Costa, A. P. R., Azevedo, D. M. M. R., Nascimento, H. T. S., Cardoso, F. S., Muratori, M. C. S. \& Lopes, J. B. 2009. Adaptabilidade climática de caprinos Saanen e zul no Meio-Norte do Brasil. Arquivo Brasileiro de Medicina Veterinária e Zootecnia, 61, 1165-1172.

Sanon, H. O., Kabore-Zoungrana, C. \& Ledin, I. 2007. Behaviour of goats, sheep and cattle and their selection of browse species on natural pasture in a Sahelian area. Small Ruminant Research, 67, 64-74.

Sevegnani, K. B., Caro, W. I., Pandorfi, H., Silva, J. O. \& Moura, D. J. 2005. Zootecnia de precisão: análise de imagens no estudo do comportamento de frangos de corte em estresse térmico. Revista Brasileira de Engenharia Agrícola e Ambiental, 9, 115-119.

Silva, A. M. A., Costa, R. G., Pereira Filho, J. M, Bakke, I. A., Lôbo, K. M. S., Lira Filho, G. E. \& Nobrega, G. H. 2010. Nutritional value of silk flower hay for lambs. Brazilian Fournal of Animal Science, 39, 2739-2743.

Silva, I. J. O., Barbosa Filho, J. A. D., Silva, M. A. N. \& Piedade, S. M. S. 2006. Influência do sistema de criação nos parâmetros comportamentais de duas linhagens de poedeiras submetidas a duas condições ambientais. Revista Brasileira de Zootecnia, 35, 1439-1446.

Staay, F. J. C. D., Joosse, M., Dijk, H. V., Schuurman, T. \& Meulen, J. V. D. 2011. Physiological and behavioral reactions elicited by simulated and real-life visual and acoustic helicopter stimuli in dairy goats. $B M C$ Veterinary Research, 7, 1746-6148.

Tracey J. P. \& Fleming P.J. S. 2007. Behavioural responses of feral goats (Capra hircus) to helicopters. Applied Animal Behaviour Science, 108, 114-128.

Vicente, L., Ferreira, M. \& Proença, V. 2002. Etologia: Glossário dos principais conceitos utilizados nas aulas práticas. Faculdade de Ciências da Universidade de Lisboa: Departamento de biologia Animal.

Weary, D. M. \& Fraser, D. 2002. Social and Reproductive Behaviour. In: The Ethology of Domestic Animals: An Introductory text. Canadá: CAB International.

Zanine, A. M., Santos, E. M., Ferreira, D. J., Graña, A. L. \& Graña, G. L. 2006. Comportamento ingestivo de ovinos e caprinos em pastagens de diferentes estruturas morfológicas. Revista Eletrônica de Veterinária, 7, 1695-7504. 